\title{
Building A Long Term Relationship Between Manufacturers And Large Retailers: Does Commitment Matter In Morocco?
}

\author{
Hicham Abbad, Université de Nantes, LEMNA, France \\ Gilles Paché, Aix-Marseille Université, CRET-LOG, France \\ Dominique Bonet Fernandez, IPAG Business School and CRET-LOG, France
}

\begin{abstract}
This paper aims to investigate present evolution in terms of relationship governance between large retailers and manufacturers in distribution channels, with a specific focus on the viability of a shift from a transactional approach to a relational approach in business exchanges. To this end, we investigate the different partners' commitment in the specific context of an emerging economy (Morocco). The findings indicate that retailers' long term orientation depends far more on their satisfaction and their dependence with respect to their suppliers than on the trust that is built up in their business relationships. Satisfaction is mainly linked to financial gain (margins and turnover generated), but also to the suppliers' marketing and logistical performance. Marketing performance concerns the quality of products, their degree of innovation, and the suppliers' promotional activity (sales drive and conditions), whilst logistical satisfaction is based on respect for deadlines, regular deliveries and compliance with orders. Very few studies have focused on business relationships between manufacturers and retailers in the specific context of emerging countries like Morocco. The present study is designed to contribute to the debate on the issue via a representative illustration through the lens of an emerging economy with the same socio-cultural background.
\end{abstract}

Keywords: Commitment; Distribution Channel; Long Term Orientation; Trust

\section{INTRODUCTION}

n many European countries, especially France and Germany, the relationship between leading retailers and industrials is characterized by confrontation and a relentless power struggle (Filser, des Garets, and Paché 2012). In the present weak economic climate, price negotiations are a sticking point that can
result in a bitter struggle and a sometimes dramatic outcome for suppliers. Very often, for want of a few centimes of euros rebate on a referenced item, manufacturers lose the possibility to sell all or part of their product line in the retailer's supermarkets and hypermarkets. We could draw the conclusion that the retailer's temporal horizon tends to be systematically short, less than a year, perhaps just a few months, with no intention to build a long term relational dynamic with the manufacturer based on commitment and trust in their shared values. While this context indisputably exists, it should not overshadow the fact that a new way of considering the exchange between retailers and manufacturers is currently emerging that is far more oriented towards the medium or the long term. Of course, price negotiations remain a key aspect of sales transactions, but it no longer excludes the will to collaborate in order to find ways to develop closer relationships and improve the efficiency of logistics systems, the introduction of products in stores, or the optimization of promotional sales operations. In other words, some retailers, more or less timidly, appear to show a desire for greater commitment to selected manufacturers, probably because they gain significant economic advantages in terms of value creation. 
The aim of the paper is to investigate current evolution in the governance of relationships between large retailers and manufacturers, notably the viability of moving from a transactional approach to business to a more relationally oriented approach. This means analyzing the commitment of partners who enter into a long term business relationship, taking the specific context of an emerging economy into consideration. In theoretical terms, this involves assessing the real interest of a relational approach to business that some authors have presented as a sort of doxa (Grönroos 1994, Gummesson 2002). From a management perspective, it implies introducing new ways of managing the marketing and logistical interfaces between firms if the trend continues, based on identifying the long term benefits of the choices jointly made by the parties concerned. Our paper is organized as follows. The first section reviews the literature on retailers' commitment, giving rise to a series of hypotheses. The second section presents the research methodology, while the third and fourth sections present and then discuss the results obtained. The fifth section assesses the managerial implications and puts forward possible avenues for future research.

\section{LITERATURE REVIEW AND HYPOTHESES}

The first classification of client-supplier relationships immediately contrasted (occasional or episodic) market relationships with the relationships enshrined in a more or less long term perspective. Early on, Macneil (1978) noted that the sphere of occasional relationships between businesses was constantly decreasing due to technical specializations and the growing complexity of business activities. In view of this evolution, business relationships which are both strong and dynamic in their adaptation to changes in the environment appear to have become increasingly important, with clients and suppliers developing joint schedules in marketing, sales promotions, logistics, etc. The notion of long term orientation in order to improve the performance of interorganizational relationships overall is reflected in the academic literature through concepts of commitment and trust in particular. Working from a conceptualization of Ganesan (1994)'s long term orientation, which the author suggests corresponds to the determination to build and maintain a long term relationship, we note that this perspective incorporates two aspects of the concept of commitment, namely, attitudinal and temporal components. In fact, these dimensions are relatively close and reflect the idea of a long term relationship (Morgan and Hunt 1994).

Unlike the concept of commitment, long term orientation is less difficult to analyze. Effectively, the instrumental component of commitment is often identified alongside the notion of specific assets in the literature, and commitment is understood as a behavior corresponding to a deliberate increase in dependence by one party. The multidimensionality of commitment can thus be confused with dependence, and because of the potential challenges in separating the two concepts, especially at the point of measurement (operationalization), some scholars, like Ganesan (1994) and Guibert (1996), have conceptualized commitment with reference to just one dimension, in other words, the client's long term orientation or the intention of one partner to maintain a relationship in the long term. While the question of differentiation between "committed" attitude, motivation, loyalty, involvement and trust remains open, Guibert (1996:85) notes that "the particular and unquestionably specific dimension of commitment ultimately seems to correspond to long term orientation." In the rest of the paper, we use the term "commitment" to designate long term orientation (the retailer's intention to maintain the relationship), which embodies the attitudinal and temporal dimensions.

\section{The Impact of Trust on Long Term Orientation}

Trust is a complex concept due to the many definitions, especially in relational marketing. Its increased interest has drawn the attention of a number of disciplines. We define trust as the presumption that each of the parties will behave in a way that corresponds to individual and shared interests. In their well-known relational KMV (key mediating variable model) marketing model, Morgan and Hunt (1994) argued that it was a major mediating variable. When analyzing the impact of trust on the stability of the client-supplier relationship, we need to take the social dimension into account since trust is dependent on the social and cultural context. Keeping this in mind, Fukuyama (1995) argues that there are various forms of trust, depending on national cultures.

According to Ganesan (1994), trust is a necessary antecedent to the long term orientation of vertical relationships between manufacturers and retailers. A retail buyer's trust in a supplier influences their long term relationships in three ways: (1) it reduces the perception of risk linked to opportunist behaviors by the supplier; (2) it 
increases the assurance for both parties that short-term difficulties and inequalities will be resolved in the long term; and (3) it reduces transaction costs in a business relationship. Ganesan (1994) argues that in such situations, retailers and manufacturers are ready to invest in specific measures likely to improve the effectiveness of their relationship and to increase the ensuing economic benefits. Trust therefore appears to have a positive impact on the likelihood of a long term relationship.

Much research has attempted to understand the adoption of specific long term trends within the retail sector, highlighting the fundamental role of trust in the different parties' intention to maintain the relationship (Ganesan 1994, Morgan and Hunt 1994, Lee and Dawes 2005, Andersen and Kumar 2006, Ruiz-Molina and GilSaura 2012). According to Wilson (1995), the notion of trust precedes commitment in a relationship. Thus, without trust, it is unlikely that the relationship will develop since trust is one of the first stages in a relationship's development. In an empirical study on the issue, Morgan and Hunt (1994) concluded that there is a negative link between trust and the propensity to break off a relationship (likelihood of a partner leaving in the near future). Finally, the impact of trust on a retailer's long term strategy can be summarized in the form of a link, resulting in the following hypothesis.

H1: The more a retailer trusts the supplier, the more the retailer will be committed to the relationship.

\section{The Impact of Dependence on Long Term Orientation}

Heide and John (1988) identify three types of determinants of dependence, arguing that a retailer's dependence on a manufacturer is stronger when: (1) the client obtains significant benefits from their relationship with the supplier with high commercial exchange value (approach with respect to sales and profit, as developed by El-Ansary and Stern [1972]); (2) the results obtained by the retailer are greater than those they could obtain with the best alternative supplier (approach with respect to satisfaction with the performance and roles, and in comparison with the level of results, as developed by Frazier [1983] and Anderson and Narus [1984]); and (3) the retailer has few alternative sources or potential for commercial exchange (approach with respect to concentration of trading options, as developed by Pfeffer and Salancik [1978]).

While a number of theoretical fields have been adopted to gain insights into the question of economic dependence in the retail sector, only a few have attempted to explain the link between economic dependence and the intention to maintain the relationship, mostly involving the theory of transaction costs and resource dependence theory. Williamson $(1975,1985)$ suggests that specific investment (dependence) stabilizes business relationships by altering the firm's incentive structure. In other words, by agreeing to specific investments in the relationship, a firm creates an incentive to maintain the relationship over the long term (Anderson and Weitz 1992). The authors also suggest that the adoption of opportunist behavior and the risk of breaking off relationships which could occur as a result are contrary to the interests of the firm making such investments. Consequently, it is more rational for the dependent party to continue their relationship with the dominant party in the distribution channel.

Several studies have focused on the management of vertical inter-organizational relationships, emphasizing the impact of symmetric dependence and strong intensity on long term orientation, commitment and cooperation (Anderson and Weitz 1992, Ganesan 1994, Razzaque and Boon 2003, Lui and Ngo 2012). Boulay (2013) underlines that dependence and power relationships between channel members can help explain the use of specific governance mechanisms. In his empirical study, Ganesan (1994) concluded that dependence had a positive impact on the long term orientation of relationships between retailers and manufacturers. Morgan and Hunt (1994) add that dependence positively influences retailers' intentions to maintain business relationships. Extending the analysis of the theoretical and empirical literature in the field, we formulate the following hypothesis relative to the potential effect of dependence on the commitment of the parties involved in the relationship.

H2: The more dependent the retailer is on the supplier, the more committed the retailer will be to the relationship. 


\section{The Impact of Satisfaction on Long Term Orientation}

In the marketing literature, satisfaction is generally presented as a positive affective state that results from an organization's assessment of all aspects of its relationship with another organization (Anderson and Narus 1984, Ruekert and Churchill 1984, Geyskens, Steenkamp, and Kumar 1999, Jap and Ganesan 2000). This is the definition we retain in our paper, as it takes in all aspects of the interactions present in the client-supplier relationships and, in addition, offers a real relational dimension. For Geyskens, Steenkamp, and Kumar (1999), the concept of satisfaction, defined as a positive affective response of a member of the distribution channel to economic and noneconomic rewards, can cover several aspects of the relationship, such as the supplier's competencies, meeting targets, the profit derived from the relationship, exchange of information, etc.

Prior research has shown that satisfaction by members of the distribution channel reduces litigation and the causes of break-downs in a relationship (Hunt and Nevin 1974, Lusch 1976). While many studies have dealt with the determinant causes of satisfaction in this respect (see Rodriques, Agudo, and Gutierrez [2006] for a literature review), few studies have analyzed the impact of satisfaction on the relationship's long term orientation. However, some scholars have identified a significant link between results-related satisfaction and commitment to a relationship (Rusbult et al. 1991). If one of the parties believes they can attain higher profit by acting alone rather by working in collaboration with one or several others, then they have no motive to invest in the relationship.

Research on the social exchange theory and the theory of justice indicates that perceived fairness in past results influences behavior in the following stages of the relationship (Adams 1965, Kelley and Thibaut 1978) and, in the context of a continuing relationship, satisfaction with regard to past results is an indicator of the fairness of the exchange (Ganesan 1994). Fair results give the assurance that the parties will behave in such a way as to attain common goals. On the other hand, when one party considers the other as unfair due to the poor results arising from the relationship, they are more wary, undermining the level of trust (Ganesan 1994). In other words, the satisfaction of one party with respect to the results and competencies of their partner increases the level of trust in a relationship (Ganesan 1994, Morgan and Hunt 1994, Jap and Ganesan 2000). To conclude, the preceding arguments may be summarized as two hypotheses.

H3a: The more satisfied the retailer with the supplier, the more committed the retailer will be to the relationship.

H3b: The more satisfied the retailer with the supplier, the more the retailer will trust the supplier.

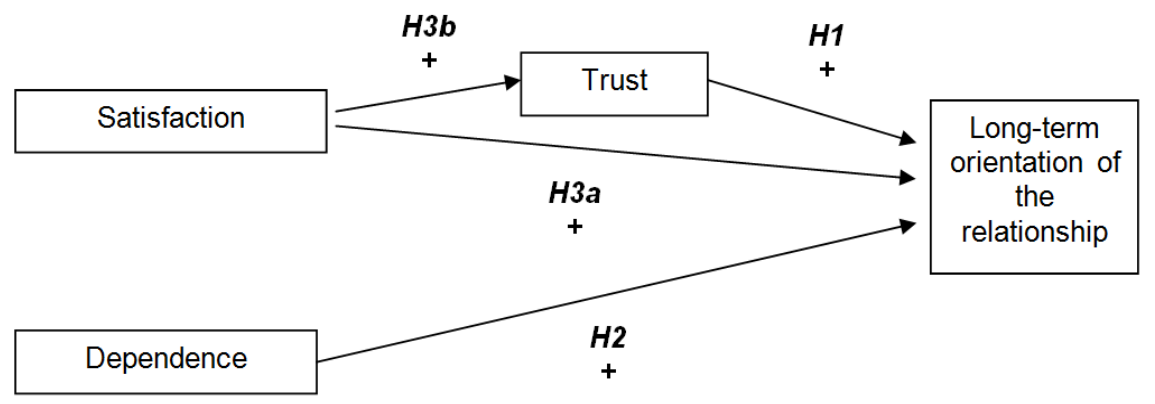

Figure 1: Model of the Retailer's Long Term Commitment

\section{METHODOLOGY}

In order to empirically test the conceptual analysis model of the retailer's long term orientation, preliminary analyses of the quantitative data needs to be carried out. This mainly involves operationalizing the variables of the proposed model to explain the data collection method used and the quality control of the measurement instruments used. 


\section{Measurement}

In the present research framework, data was collected through a 29-item questionnaire (see Table 1). To make the "retailer's long term orientation" variable operational, we opted for the measurement developed by Ganesan (1994) which includes seven items. For the mediating variable (trust), we chose the measurement developed by Morgan and Hunt (1994) which, according to the authors, is a scale that contains the main dimensions of trust, in other words, reliability, integrity and "firm belief". The seven items were adapted to the interorganizational context under study. Dependence was measured using one of the two indicators proposed by Ganesan (1994), in other words, eight items that reflect the importance of the partner in the exchange. The satisfaction measurement tool was based on the work by Anderson and Narus (1990) and Morgan and Hunt (1994). The variable is operationalized by asking the respondents to assess the performance of their suppliers in a range of areas: sales promotion operations, logistics, product quality, price, income obtained (turnover) and the margins realized. The scales used to measure the first three variables were 7-point Likert scales that ranged from "I don't agree at all" to "I fully agree", while satisfaction was calculated according to a seven-point scale ranging from "very unsatisfied" to "very satisfied".

Table 1: Measurement Scales

Indicators $\quad$ References

Retailer's long-term orientation
(ORIENLTD1) We believe that our relationship with this supplier will be profitable in the long term.
(ORIENLTD2) It is important for us to maintain a relationship with this supplier in the long term.
(ORIENLTD3) We are concentrating on achieving our long-term goals in this relationship.
(ORIENLTD4) We are ready to make sacrifices to help this supplier from time to time.
(ORIENLTD5) Only the results interest us in this relationship (R).
(ORIENLTD6) We expect to work with this supplier for a long time.
(ORIENLTD7) All the concessions that we make to help this supplier will prove worthwhile in the
long term.

Retailer's trust in their supplier

(CONFID1) We cannot always trust this supplier (R).

(CONFID2) This supplier is perfectly honest and loyal.

(CONFID3) We can trust this supplier entirely.

(CONFID4) We can count on this supplier to do his work correctly.

Morgan and Hunt

(CONFID5) This supplier is truly trustworthy.

(CONFID6) Personally, I have great trust in this supplier.

(CONFID7) This supplier is extremely honest.

\section{Dependence of the retailer on the supplier}

(DEPENDD1) If we broke off relationships with this supplier it would be difficult for us to make up

the sales volumes.

(DEPENDD2) This supplier is crucial to our future performance.

(DEPENDD3) It would be difficult for us to replace this supplier.

(DEPENDD4) We depend on this supplier.

Ganesan (1994)

(DEPENDD5) We do not have a good alternative for this supplier.

(DEPENDD6) This supplier is important for our activity.

(DEPENDD7) This supplier's products are important in our product offer.

(DEPENDD8) If we broke off relationships with this supplier, it would be very difficult to replace him.

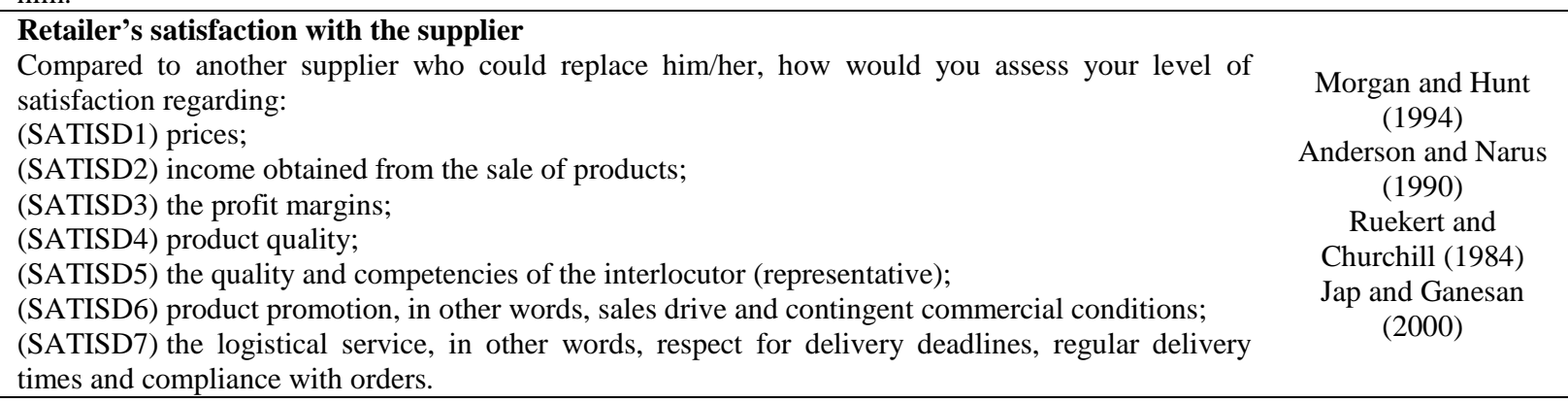

(R) Reversed response scale. 


\section{Sample Population and Respondents}

The chosen emerging country is Morocco, one of the three North African countries that were under French influence for many years. Morocco has been experiencing a rapid transformation of its commercial infrastructures during the last ten years in the major cities of the Kingdom. At present, five firms share the modern retailing industry: Marjane, Carrefour, Aswak Assalam, Carrefour Market-Label' Vie and Acima (see Table 2). However, the firms' market segments are distinct: some companies are specialized in selling to consumers in large supermarkets (Aswak Assalam and Marjane) or medium-sized ones (Carrefour Market-Label' Vie and Acima). As Amine and Lazzaoui (2011:566) note, "the supermarket or hypermarket is now used to endow sophisticated or refined products, while traditional shops continue to have priority for the purchase of common consumption goods. Even if the traditional commerce resists, the main trend shows that traditional commerce based on interpersonal contact is gradually replaced by the self-service concept especially in urban areas in the emerging countries".

Table 2: Some Data on the Modern Retailing Industry in Morocco (December 2012)

\begin{tabular}{|c|c|c|c|c|}
\hline & Owner & $\begin{array}{c}\text { Opening of First } \\
\text { Store }\end{array}$ & $\begin{array}{c}\text { Number of } \\
\text { Stores }\end{array}$ & Locations \\
\hline Acima & SNI & 2002 & 33 & $\begin{array}{l}\text { Aït Melloul (1), Beni Mellal (1), Berrechid } \\
\text { (1), Casablanca (12), El Jadida (1), Fez (2), } \\
\text { Khouribga (1), Marrakech (3), Meknès (1), } \\
\text { Mohammedia (1), Rabat (2), Safi (1), Salé } \\
\text { (1), Tangiers (3), Témara (1), Tétouan (1) }\end{array}$ \\
\hline $\begin{array}{l}\text { Aswak } \\
\text { Assalam }\end{array}$ & $\begin{array}{l}\text { YNNA Holding (in } \\
\text { partnership with } \\
\text { Casino) }\end{array}$ & 1998 & 12 & $\begin{array}{c}\text { Agadir (2), Casablanca (1), Essaouira (1), } \\
\text { Kénitra (1), Marrakech (2), Mohammedia (1), } \\
\text { Oujda (1), Rabat (1), Tangiers (1), Témara } \\
\text { (1) }\end{array}$ \\
\hline Carrefour & $\begin{array}{l}\text { Best Financière (in } \\
\text { partnership with } \\
\text { Carrefour) }\end{array}$ & 2009 & 10 & $\begin{array}{c}\text { Agadir (1), Casablanca (2), Fez (1), } \\
\text { Marrakech (2), Oujda (1), Rabat (1), Salé (1), } \\
\text { Tangiers (1) }\end{array}$ \\
\hline $\begin{array}{l}\text { Carrefour } \\
\text { Market- } \\
\text { Label' Vie }\end{array}$ & $\begin{array}{l}\text { Best Financière (in } \\
\text { partnership with } \\
\text { Carrefour) }\end{array}$ & 1986 & 34 & $\begin{array}{c}\text { Agadir (2), Casablanca (12), El Jadida (1), } \\
\text { Fez (1), Kénitra (2), Khemisset (1), } \\
\text { Marrakech (1), Meknès (2), Mohammedia } \\
\text { (2), Rabat (6), Salé (1), Settat (1), Sidi } \\
\text { Slimane (1), Témara (1) }\end{array}$ \\
\hline Marjane & SNI & 1991 & 29 & $\begin{array}{c}\text { Agadir (1), Beni Mellal (1), Casablanca (5), } \\
\text { El Hoceima (1), Fez (2), Fkih Bensalah (1), } \\
\text { Kelâat Es-Sraghna (1), Kénitra (1), } \\
\text { Khouribga (1), Marrakech (2), Meknès (1), } \\
\text { Mohammedi (1), Nador (1), Oujda (1), Rabat } \\
\text { (2), Safi (1), Saïdia (1), Salé (1), Tangiers (2), } \\
\text { Taza (1), Tétouan (1) }\end{array}$ \\
\hline
\end{tabular}

The questionnaire was administered in person to retail buyers from the five leading retailers operating in the Moroccan retail market. Face-to-face interviews are widely considered to be the best technique when questioning interlocutors from a specific sociocultural context characterized by mistrust of the written word and a predominance of oral communication and direct discussion (Tangeaoui 1993, Sabri 2012). The basis of the survey used was developed during the first exploratory phase of the study. The questionnaire was pre-tested with two of the purchasing managers in order to check its clarity and to add any changes required. In all, we obtained 50 usable questionnaires after sending out requests for completion. We should add that only one respondent (purchasing manager for the Moroccan leader) was French.

\section{Analysis Methods}

The quantitative data was processed in two stages: the first aimed to assess the validity and reliability of the measurements used, whilst the second aimed to test the relationships between the model variables. The measurement scales were based on Churchill (1979)'s paradigm. To test our research model hypotheses, we used the regression method and, more specifically, a forward sequential procedure, in other words, a stepwise regression. To enable us to highlight the actual status of the supposedly mediating variable (retailer's trust of his/her supplier), we used the 
technique developed by Baron and Kenny (1986) who suggested a three-stage process using independent regressions: regression of the independent variable on the mediating variable (equation 1); regression of the independent variable on the dependent variable (equation 2) and regression of the independent and mediating variables on the dependent variable (equation 3).

\section{RESULTS}

After assessing the quality of the measurement tools, the interactions between independent variables, the mediating variable and the dependent variable were tested using suitable statistical methods and the results are discussed below. The tests to measure the validity and reliability of the scales were carried out successively using factor analysis to analyze the main components and Cronbach's Alpha. The study was based on both face and consensus (researcher's appraisal) validity, and on the validity of the characteristic or the construct (factor contributions above 0,5 calculated through the analyses of the main components). The validity and reliability of all the measurement scales proposed was satisfactory. Overall, they present good internal consistency.

The application of Baron and Kenny (1986)'s model to our sample population led us to test all of the links put forward between the explanatory variables and the dependent variable: i.e., the retailer's commitment to the relationship. These links were tested using simple and multiple regressions: the impact of independent variables, satisfaction and dependence on the dependent variable, the influence of the "satisfaction" variable on the variable assumed to mediate trust, and the impact of the mediating variable on the dependent variable. The results obtained indicate that the regression model is globally satisfactory. The Fisher-Snedecor test, significant at a threshold of $1 \%$, indicated a correlation between the explanatory variables and the variable to be explained: i.e., retailer's commitment. The model's overall precision, measured by the adjusted coefficient of determination $\mathrm{R}^{2}$, indicates that $68 \%$ of the variation of the dependent variable may be explained by the independent variables defined in the regression model. This allowed us to conclude that there was a significant effect of explanatory variables on the retailer's long term orientation.

The initial model evaluated has four explanatory variables. These are the four principal factors retained from the PCA. As mentioned earlier, a stepwise sequential process was used to assess the relative weight of each independent variable to define the retailer's commitment. This involved eliminating the variables whose regression coefficients (link with the dependent variable) were the least significant. Table 2 shows that only the retailer's trust in their supplier variable was withdrawn from the regression equation due to its low explanatory power. On the other hand, the regression analysis identified other statistically significant variables and positive regression coefficients (in other words, with the character expected). The three variables are in decreasing order of contribution, namely, retailer's satisfaction with the product quality and financial returns (SATISC1), satisfaction with the retailer's logistical and marketing performance (SATISC2) and the retailer's dependence on the supplier (DEPENDC) (see Table 3).

Table 3: Estimation of the Regression Equation Coefficients of Retailers' Long Term Orientation

\begin{tabular}{|c|c|c|c|c|}
\hline $\begin{array}{c}\text { Explanatory } \\
\text { Variables }\end{array}$ & $\begin{array}{c}\text { Non-Standardized } \\
\text { Regression } \\
\text { Coefficient (B) } \\
\end{array}$ & $\begin{array}{c}\text { Standardized } \\
\text { Regression } \\
\text { Coefficient (Beta) }\end{array}$ & $\begin{array}{c}\text { Student's t-test } \\
\text { (Significance of } t \\
\text { test) }\end{array}$ & $\begin{array}{c}\text { Simple Correlation } \\
\text { Coefficient }\end{array}$ \\
\hline \multicolumn{5}{|c|}{ Variables included in the regression } \\
\hline SATISC1 & 0,551 & 0,463 & $\begin{array}{c}4,460 \\
(0,000)^{* * *}\end{array}$ & $0,753 * * *$ \\
\hline SATISC2 & 0,337 & 0,292 & $\begin{array}{c}3,173 \\
(0,003)^{* * *}\end{array}$ & $0,600 * * *$ \\
\hline DEPENDC & 0,296 & 0,281 & $\begin{array}{c}2,922 \\
(0,005)^{* * *}\end{array}$ & $0,623 * * *$ \\
\hline Constant & $-0,381$ & & $\begin{array}{c}-0,758 \\
(0,452)^{\text {n.s. }}\end{array}$ & \\
\hline $\begin{array}{c}\text { Variables exclude } \\
\text { CONFIC }\end{array}$ & the regression & 0,108 & $\begin{array}{c}1,089 \\
(0,282)^{\text {n.s. }}\end{array}$ & $0,545 * * *$ \\
\hline
\end{tabular}

*** The parameters are significant at a threshold of $1 \%(\mathrm{p}<0.01)$. n.s. The parameters are not significant. 
The correlation matrix between the independent variables and the dependent variable confirms the results obtained. In effect, the satisfaction variable in terms of quality and financial returns (SATISC1) correlates most closely with the dependent variable: i.e., retailer's commitment $(0,75)$. Correlation of the logistical and marketing variables with retailers' commitment indicates a significant value of 0,60 . Retailers' dependence (DEPENDC) also presents a significant correlation with the variable explained (i.e., 0,62). Given these results, we can confirm hypothesis $\mathrm{H} 3 \mathrm{a}, \mathrm{H} 2$ and reject hypothesis $\mathrm{H} 1$. The research hypothesis inherent to the link between satisfaction and trust was tested by simple regressions (equation 1). The main results obtained are set out in Table 4. The analysis is explained variable by variable. The explanatory variables SATISC1, SATISC2 have a significant and positive impact on retailers' trust. The expected relationships, postulating the link between these explanatory variables and trust, were positive and confirmed. Hypothesis H3b is therefore confirmed.

Table 4: The Influence of Satisfaction on the Mediating Variable "Retailers' Trust"

\begin{tabular}{lccc}
\hline Explanatory Variables & $\begin{array}{c}\text { Non-Standardized } \\
\text { Regression Coefficient (B) }\end{array}$ & $\begin{array}{c}\text { Student's t-test (Significance } \\
\text { of t test) }\end{array}$ & $\begin{array}{c}\mathbf{R}^{2} \\
\text { (Test in F) }\end{array}$ \\
\hline SATISC1 & 0,538 & 4,780 & 0,323 \\
& & $(0,000)^{* * *}$ & $(22,852)^{* * *}$ \\
SATISC2 & 0,331 & 2,680 & 0,130 \\
& & $(0,010)^{* * *}$ & $(7,183)^{* * *}$ \\
\hline
\end{tabular}

*** The parameters are significant at a threshold of $1 \%(\mathrm{p}<0,01)$

In order to evaluate the influence of the mediating variable of trust on retailers' commitment (equation 3), we carried out analyses of multiple regressions successively conducted with the mediating variable "trust" and the independent variable of retailers' commitment. The results of all the analyses are summarized in Table 5. They indicate for each regression equation, the non-standardized regression coefficient (B), the standardized regression coefficient (Beta), the Student's $t$ test and its significance, the coefficient of determination $\mathrm{R}^{2}$, and the FisherSnedecor test and its significance. In line with Baron and Kenny (1986)'s process, the mediating nature of a variable in a model is evaluated by the significance of the coefficient relative to the independent variable.

Table 5: Influence of the Mediating Variable of Trust on the Retailer's Long Term Orientation

\begin{tabular}{lcccc}
\hline $\begin{array}{c}\text { Explanatory } \\
\text { Variables }\end{array}$ & $\begin{array}{c}\text { Non-Standardized } \\
\text { Regression } \\
\text { Coefficient (B) }\end{array}$ & $\begin{array}{c}\text { Standardized } \\
\text { Regression } \\
\text { Coefficient (Beta) }\end{array}$ & $\begin{array}{c}\text { Student's t-test } \\
\text { (Significance of t test) }\end{array}$ & $\begin{array}{c}\text { R } \mathbf{F} \text { Test } \\
\text { (Significance of F } \\
\text { test) }\end{array}$ \\
\hline SATISC1 & 0,778 & 0,654 & 5,750 & 0,588 \\
CONFIC & 0,218 & 0,174 & $\begin{array}{c}1,525 \\
(0,134)^{\text {n.s }}\end{array}$ & $\begin{array}{c}33,472 \\
(0,000)^{* * *}\end{array}$ \\
\hline SATISC2 & 0,534 & 0,464 & 4,128 & 0,484 \\
CONFIC & 0,474 & 0,378 & 3,366 & 22,072 \\
\end{tabular}

*** The parameters are significant at a threshold of $1 \%(\mathrm{p}<0,01)$. n.s. The parameter is not significant.

The results of the two equations 1 and 2, compared with those of equation 3, indicate that the mediating effect of trust is not confirmed. Indeed, the results of equation 3 relative to the influence of trust and satisfaction regarding quality and financial returns (SATISC1) indicate that trust is non-significant and cannot be considered as a mediating variable between the independent variable and retailers' long term orientation. Concerning the relationship between retailers' satisfaction with marketing and logistics (independent variable coded SATISC2) and their long term orientation (dependent variable), trust does not appear to be a mediating variable. In effect, when all three of Baron and Kenny (1986)'s conditions are present, the effect of the independent variable SATISC2 is higher in equation 3 than in equation 2. 


\section{DISCUSSION}

Our initial aim in conducting this study was to identify key variables that explained long term orientation in retailer/supplier relationships. The focus was primarily on satisfaction, dependence and trust. Our research findings give insights into what leads retailer and supplier relationships to take a long term orientation.

1. With regard to satisfaction, we argue that hypothesis H3a is confirmed insofar as both aspects of retailer satisfaction (i.e., satisfaction with financial returns and product quality and satisfaction with marketing and logistical performance) are considered as explanatory variables in the intention to maintain a relationship. Retailers certainly attach considerable importance to financial returns (margins and turnover) but are also interested in areas that can increase these returns (product quality, product promotion, supplier's logistics). While the aspect of product promotion (sales drive and contingent commercial conditions) guarantees retailers immediate financial returns, mainly in the form of back margins, improved product quality (innovation, packaging, etc.) and the optimization of logistics services (respect for delivery delays, regular deliveries, compliance with orders, etc.) can constitute major areas of financial gain with the help of genuine support policies and/or by the pressure exercised on the manufacturers. We suggest that a retailer's intention to maintain a long term relationship by annually renewing their suppliers' contracts is mainly determined by respect for economic efficiency. These results are in line with those of other authors mentioned in our literature review, and confirm the close link between satisfaction with results and commitment to a relationship (Rusbult et al. 1991, Ganesan 1994, Morgan and Hunt 1994, Jap and Ganesan 2000).

2. Not surprisingly, dependence is a key explanatory variable in long term orientation. Hypothesis $\mathrm{H} 2$ postulated that the more dependent the retailer is on his/her supplier, the greater the commitment to long term orientation, and this was confirmed. Our results concur with those found in the literature. Heide and John (1988) argued that retailers are more dependent on their suppliers when the results and the value the client obtains from the relationship with their supplier are highly beneficial. Williamson $(1975,1985)$ adds that specific investments (dependence) stabilize relationships over time by transforming the firm's incentive structure and fostering long term orientation, commitment and cooperation (Anderson and Weitz 1992, Ganesan 1994). Ganesan (1994) and Morgan and Hunt (1994) conclude that dependence has a positive impact on the long term orientation of relationships and that it has a positive influence on the intention of members of the distribution channel to maintain business relationships. Our results confirm prior research regarding the influence of dependence on the long term orientation of relationships.

3. Hypothesis H1 states that the more the retailer trusts his/her supplier, the more committed they will be to the relationship. Our findings indicate that the retailers' trust of their supplier does not appear to have a significant positive impact on their long term orientation (hypothesis H1 rejected). However, many examples in the literature highlight the significant role of trust. According to Ganesan (1994), trust is a crucial antecedent to the long term orientation of vertical relationships between manufacturers and retailers. On the same way, Morgan and Hunt (1994), Wilson (1995), Lee and Dawes (2005) and Andersen and Kumar (2006) highlight the crucial role of trust in the intention of the different parties to maintain a relationship.

One explanation for this difference may be that in the Moroccan cultural context, trust is simply not as important for stable and sustainable relationships between retailers and food sector manufacturers as it is in AngloSaxon countries. The degree of trust remains low due to the formalization of trade and logistics agreements between the two players in the distribution channel; in business relationships in Morocco, a contract or written agreement is generally considered to be a strong signal of lack of confidence. By using the typology developed by Fukuyama (1995), Morocco appears to be one of the societies where the level of trust is low outside family structures which are culturally strong and supportive.

\section{MANAGERIAL IMPLICATIONS}

The study findings indicate that retailers' long term orientation depends on their satisfaction and their dependence on their suppliers. Satisfaction is mainly linked to financial gain (margins and turnover generated), but also on the suppliers' marketing and logistical performance. Marketing performance concerns product quality, the 
degree of innovation, and the suppliers' sales drive and conditions, whilst logistical satisfaction is based on respect for deadlines, regular deliveries and compliance with orders. Thus, the retailer's dependence on their supplier plays a key role in the pursuit of a relationship. The suppliers' impact on sales results, the difficulty of replacing them and the inexistence of alternative suppliers are key factors in a retailer's long term commitment. These results enable us to make managerial recommendations to manufacturers operating in the food sector, as well as to governments and large retailers.

The critical dimensions identified provide us with a clear long term supplier profile. Suppliers need to provide products (and associated services) that generate both economic value and strong potential differentiation to the extent that the retailer cannot do without them. These different elements, linked to logistics management that respects the cost/quality/reactivity triptych, increase the likelihood of stable and sustainable relationships. In the face of rapid changes in manufacturers' competitive environment (increase in food imports, mainly from Europe), a stable and long term relationship with fast-growing retail leaders is a key objective for management in industrial structures. Cooperation could become a strategy in its own right on condition that the manufacturers are keen to pursue the commercial relationship in the long term. This determination is conditioned by three principal elements: satisfaction with regard to financial returns and product quality, satisfaction in the area of logistics and marketing, and the retailer's dependence on their supplier. The first two elements require collaboration between the manufacturers and the retailer and considerable financial resources (development of turnover, improvement in product quality, increased logistical and marketing know-how), while the third is inherent in the products marketed by the manufacturers.

To increase the retailers' dependence and thereby guarantee stability in the relationship, manufacturers must first enter niche markets where the number of existing suppliers is relatively low and, second, develop an offer with an original, distinctive and innovative character. In Morocco, diverse opportunities available in the large-scale food retail sector could form one of the main organizational conditions for suppliers' development (organizational learning, access to national and international markets, access to financial resources, increase in sales in terms of turnover and volume, economies of scale). Our study contributes to insights on the decision-making aspects of retail buyers when extending annual contracts. These factors should give Moroccan manufacturers a clearer understanding of key aspects of their relationships with the leading large retailers.

The government should also find our results of interest as they offer useful insights into ways to develop more effective support policies for food industry firms and business owners. These policies concern a certain number of areas that could be enhanced and/or reorganized in the medium term, notably the suppliers' marketing and logistical competencies. Having worked for many years in a local market, leading retailers now ask many suppliers to supply stores in towns and cities across Morocco. To facilitate the circulation of physical flows, the government needs to invest significantly in the country's physical infrastructures (roads, free trade zones, warehouses, etc.) and technological infrastructures (telecommunications) in order to optimize the physical flows and the circulation of informational flows. The actions of Moroccan law-makers could also impact on the suppliers' marketing and logistical capacity. Among other things, this involves organizing training sessions, and morally and financially helping institutions that represent Moroccan entrepreneurs (e.g., the National Food Industry Federation), as well as developing substantial support policies. All the recommendations presented herein can help to improve marketing and logistical relationships between the leading retailers and their suppliers.

The "good supplier" profile that we identified in the study is very similar to the profile sector professionals in Europe have understood for many years, but it is interesting to note that the results obtained are comparable with the context of an emerging country. We believe that one of the main contributions of the paper is the clearly universal nature of the management measures that facilitate the development of a relational vision in relationships between industrials and retailers. However, there is still a need for the sometimes fragile and poorly structured local suppliers to be brought up to the standards of modern distribution regarding aspects that range from production conditions to the marketing and logistical management of their products. Retailers need to work in this direction if they wish to establish lasting links with the best performing and most reactive suppliers. This dynamic will be stronger if the government has the political will to modernize the country and provide it with an institutional environment that promotes foreign investment. 


\section{CONCLUSIONS}

This paper is in line with marketing and strategic management literature, and so it is not really a surprise that retailers' long term orientation depends far more on their satisfaction and the dependence on their suppliers than on the trust that develops in their business relationships. Satisfaction is mainly linked to the associated financial gains (margins and turnover generated), but also on the suppliers' marketing and logistical performance. Marketing performance is reflected in product quality, degree of innovation, and promotional performance (sales drive and conditions), whilst logistical satisfaction is based on respect for deadlines, regular deliveries and compliance with orders. In parallel, retailers' dependence on their supplier plays a large role in the pursuit of a relationship. Thus, the supplier's importance in relation to sales, the difficulty of replacing them in the event of a product being delisted and the inexistence of alternative suppliers are key elements with respect to long term orientation, which corresponds to the findings by Porter (1980) more than thirty years ago.

The critical dimensions identified enable us to draw up a clear long term supplier profile. The latter must, above all, offer products (and associated services) that generate economic value and have high differentiation potential, so that the retailer cannot do without them. These different factors, combined with logistics management that respects the cost/quality/reactivity triptych, will help increase the likelihood of stable and lasting business relationships being maintained. This conclusion is consistent with the research of Ruiz-Molina and Gil-Saura (2012) conducted in Spain, which emphasizes a positive influence of relationship value on long term orientation and commitment in distribution channels. Ultimately, the profile of the "good supplier" identified here is very similar to what European sector professionals have understood for many years, but it is interesting to note that comparable results are obtained in the context of an emerging economy; we believe that one of the paper's main contributions is to clearly underscore the universal nature of management processes that help to promote a relational vision between manufacturers and retailers. However, the sometimes fragile and poorly structured local suppliers still need help to update their structures in line with modern distribution norms, from the production conditions to their product marketing and logistics management. Retailers need to make an effort in this area if they wish to develop long term ties with the most efficient and most reactive suppliers.

Given the limited nature of our research, at least in geographic terms (the Moroccan context), we aim to extend our observations to other North African and Middle Eastern countries. A comparative approach would be interesting insofar as the countries on the south of the Mediterranean basin (Morocco, Algeria, Tunisia, Egypt) share a common cultural basis in terms of history, language, customs, religion, etc., but also present non negligible points of divergence, particularly in terms of influence of the institutional framework on the economic activity. The literature on retail networks expansion, particularly franchises in emerging countries, is full of examples where we can observe the facilitating role of the government and the institutional framework in the development of networks in most of the emerging economies (Isa et al. 2012, Yu and Ramanathan 2012). This promising avenue should enable us to contribute to improving our understanding of decision-making processes in an increasingly globalized world.

\section{AUTHOR INFORMATION}

Hicham Abbad is an Assistant Professor of Marketing and Logistics at the Universite de Nantes and a member of the Laboratoire d'Economie et de Management de Nantes Atlantique (LEMNA), France. His research fields include inter-firm relationships and more precisely the manufacturing-retailing relationships. In his research he is particularly interested in the logistical and marketing aspects in the supplier-buyer exchanges at the national and international level. E-mail: hicham.abbad@univ-nantes.fr

Gilles Paché is Professor of Retailing and Supply Chain Management at the Aix-Marseille Université, France. He has more than 300 publications in the forms of journal papers, books, edited books, edited proceedings, edited special issues, book chapters, conference papers, and reports. He is Deputy Director of the Centre de Recherche sur le Transport et la Logistique (CRET-LOG) in Aix-en-Provence, and his major interests are network organizations, supply chain management, and retail operations management. E-mail: gilles.pache@univ-amu.fr (Corresponding author) 
Dominique Bonet Fernandez is Professor of Marketing and researcher at IPAG Business School in Paris, and associate researcher at the CRET-LOG, France. After several years in the industry as a brand manager, she received her $\mathrm{PhD}$ in Management and an Habilitation à Diriger des Recherches (HDR) at Aix-Marseille Université. She is an MBA graduate from HEC Montreal and McGill University. Her research fields include issues regarding intra and interorganizational relationships and the international distribution strategies. E-mail: dominique.bonetfernandez@ipag.fr

\section{REFERENCES}

1. Adams, S. (1965). Inequity in social exchange In Advances in experimental social psychology (Vol. 2), ed. L. Berkowitz, 267-299. New York: Academic Press.

2. Amine, A. and N. Lazzaoui (2011). Shoppers' reactions to modern food retailing systems in an emerging country: The case of Morocco. International Journal of Retail \& Distribution Management 39(8) 562-581.

3. Andersen, P. and R. Kumar (2006). Emotions, trust and relationship development in business relationships: A conceptual model for buyer-seller dyads. Industrial Marketing Management 35(4) 522-535.

4. Anderson, E. and B. Weitz (1992). The use of pledges to build and sustain commitment in distribution channels. Journal of Marketing Research 24(1) 18-34.

5. Anderson, J. and J. Narus (1984). A model of the distributor's perspective of distributor-manufacturer working relationships. Journal of Marketing 48(4) 62-74.

6. Anderson, J. and J. Narus (1990). A model of distributor firm and manufacturer firm working partnerships. Journal of Marketing 54(1) 42-58.

7. Baron, R. and D. Kenny (1986). The moderator-mediator variable distinction in social psychological research: Conceptual, strategic, and statistical considerations. Journal of Personality and Social Psychology 51(6) 1173-1182.

8. Boulay, J. (2013). Contractual governance, relational governance: Why do firms continue drafting contracts? Journal of Applied Business Research 29(3) 863-870.

9. Churchill, G. (1979). A paradigm for developing better measures of marketing constructs. Journal of Marketing Research 16(1) 64-73.

10. El-Ansary, A. and L. Stern (1972). Power measurement in the distribution channel. Journal of Marketing Research 9(1) 47-52.

11. Filser, M., V. des Garets and G. Paché (2012). La distribution: Organisation et stratégie (2 ${ }^{\text {nd }}$ ed.). Caen: Editions Management \& Société.

12. Frazier, G. (1983). On the measurement of interfirm power in channels of distribution. Journal of Marketing Research 20(2) 158-166.

13. Fukuyama, F. (1995). Trust: The social virtues and the creation of prosperity. New York: Free Press.

14. Ganesan, S. (1994). Determinants of long term orientation in buyer-seller relationships. Journal of Marketing 58(2) 1-19.

15. Geyskens, I., J.-B. Steenkamp and N. Kumar (1999). A meta-analysis of satisfaction in marketing channel relationships. Journal of Marketing Research 36(2) 223-238.

16. Grönroos, C. (1994). Quo vadis, marketing? Toward a relationship marketing paradigm. Journal of Marketing Management 10(5) 347-360.

17. Guibert, N. (1996). La relation client-fournisseur et les nouvelles technologies de l'information: Le rôle des concepts de confiance et d'engagement. Unpublished doctoral dissertation, Montpellier: Université des Sciences et Techniques du Languedoc-Montpellier II.

18. Gummesson, E. (2002). Total relationship marketing: Rethinking marketing management. London: Butterworth-Heinemann.

19. Heide, J.-B. and G. John (1988). The role of dependence balancing in safeguarding transaction-specific assets in conventional channels. Journal of Marketing 52(1) 20-35.

20. Hunt, S. and J. Nevin (1974). Power in a channel of distribution: Sources and consequences. Journal of Marketing Research 11(2) 186-193.

21. Isa, F., C. Hoe, S. Othman, M. Din, M. Mohd Harif, Z. Hussin and M. Jani (2012). The extent of marketing capability and market orientation in franchise business in Malaysia. International Journal of Business \& Social Science 3(10) 325-334. 
22. Jap, S. and S. Ganesan (2000). Control mechanisms and the relationship life cycle: Implications for safeguarding specific investments and developing commitment. Journal of Marketing Research 37(2) 227 245.

23. Kelley, H. and J. Thibaut (1978). Interpersonal relations: A theory of interdependence. New York: John Wiley \& Sons.

24. Lee, D. and P. Dawes (2005). Guanxi, trust, and long-term orientation in Chinese business markets. Journal of International Marketing 13(2) 28-58.

25. Lui, S. and H.-Y. Ngo (2012). Drivers and outcomes of long-term orientation in cooperative relationships. British Journal of Management 23(1) 80-95.

26. Lusch, R. (1976). Sources of power: Their impact on intra-channel conflict. Journal of Marketing Research 13(3) 382-390.

27. Macneil, I. (1978). Contracts: Adjustment of long-term economic relations under classical, neo-classical, and relational contract law. Northwestern University Law Review 72(6) 854-906.

28. Morgan, R. and S. Hunt (1994). The commitment-trust theory of relationship marketing. Journal of Marketing 58(3) 20-38.

29. Pfeffer, J. and G. Salancik (1978). The external control of organizations: A resource dependence perspective. New York: Harper \& Row.

30. Porter, M. (1980). Competitive strategy: Techniques for analyzing industries and competitors. New York: Free Press.

31. Razzaque, M.-A. and T.-G. Boon (2003). Effects of dependence and trust on channel satisfaction, commitment and cooperation. Journal of Business-to-Business Marketing 10(4) 23-48.

32. Rodriques, R., J. Agudo and H. Gutierrez (2006). Determinants of economic and social satisfaction in manufacturer-distributor relationships. Industrial Marketing Management 35(6) 666-675.

33. Ruekert, R. and J. Churchill (1984). Reliability and validity of alternatives measures of channel member satisfaction. Journal of Marketing Research 21(2) 226-233.

34. Ruiz-Molina, M.-E. and I. Gil-Saura (2012). Relationship and market conditions: Outcomes in marketing channels. Journal of Business-to-Business Marketing 19(4) 289-308.

35. Rusbult, C., J. Verette, G. Whitney, L. Slovik and I. Lipkus (1991). Accommodation processes in close relationships: Theory and preliminary empirical evidence. Journal of Personality and Social Psychology 60(1) 53-78.

36. Sabri, R. (2012). L'accompagnement comme pratique de légitimation en grande distribution: Le cas de Marjane Holding. Unpublished doctoral dissertation, Montpellier: Université Montpellier I.

37. Tangeaoui, S. (1993). Les entrepreneurs marocains: Pouvoir, société et modernité. Paris: Editions Karthala.

38. Williamson, O. (1975). Markets and hierarchies: Analysis and antitrust implications. New York: Free Press.

39. Williamson, O. (1985). The economic institutions of capitalism: Firms, markets, relational contracting. New York: Free Press.

40. Wilson, D. (1995). An integrated model of buyer-seller relationships. Journal of the Academy of Marketing Science 23(4) 335-345.

41. Yu, W. and R. Ramanathan (2012). Effects of business environment on international retail operations: Case study evidence from China. International Journal of Retail \& Distribution Management 40(3) 218-234. 


\section{NOTES}

